\title{
Managing the healthcare demand-supply gap during and after COVID-19: The need to review the approach to healthcare priority-setting in South Africa
}

\author{
G C Solanki, ${ }^{1,23}$ BChD, BA Hons, MSc, DrPH; T Wilkinson, ${ }^{2}$ BPharm, MSc (Health Economics); E Daviaud, ${ }^{1}$ MSc (Economics, \\ Health Economics), MPhil (Sociology of Development); D Besada, ${ }^{1}$ BSc, MPH (Epidemiology and Biostatistics), PG Dip (Health Economics); \\ C R Tamandjou Tchuem, ${ }^{2}$ BSc (Medical Physiology), MSc (Medical Virology), PhD; S Docrat, ${ }^{2}$ BSc, MPH (Health Economics); \\ S M Cleary, ${ }^{2} \mathrm{BA}$, BA Hons, MA (Economics), $\mathrm{PhD}$ \\ ${ }^{1}$ Health Systems Research Unit, South African Medical Research Council, Cape Town, South Africa \\ ${ }^{2}$ Health Economics Unit, School of Public Health and Family Medicine, Faculty of Health Sciences, University of Cape Town, South Africa \\ ${ }^{3}$ NMG Consultants and Actuaries, Cape Town, South Africa
}

Corresponding author: G C Solanki (geetesh.solanki@mrc.ac.za)

Healthcare demands are rising globally, and regardless of the approach to financing and delivering healthcare services, no country can meet all the healthcare demands of its population. The demand-supply gap for healthcare services in South Africa (SA) is large, particularly for the public sector. The objectives of this article are to examine some of the underlying factors contributing to this gap, and how the COVID19 pandemic is likely to impact on them, and to describe why SA needs to adopt an explicit and equity-informed approach to healthcare priority-setting to assist in managing the gap.

S Afr Med J 2021;111(1):20-22. https://doi.org/10.7196/SAMJ.2021.v111i1.15239

Healthcare demands are rising globally as a result of demographic changes, ongoing development of new healthcare technologies and interventions, and rising consumer expectations. No matter what the level of expenditure and regardless of the methods of financing and delivery that are adopted, no country can meet all the claims on healthcare of its population. The gap between the demand for healthcare and the ability of the South African (SA) healthcare system to meet those needs (demand-supply gap) is well documented. ${ }^{[1]}$ However, SA does not have a consistent, co-ordinated and transparent mechanism for setting priorities to manage this gap. The objectives of this article are to examine some of the underlying factors contributing to this gap, and how the COVID-19 pandemic is likely to impact on them, and to describe why SA needs to adopt an equity-informed approach to explicit priority-setting to assist in managing the gap, now and in the future.

\section{The healthcare demand-supply gap in SA}

As per the Constitution of the World Health Organization, ${ }^{[2]}$ 'Every human being has the right to have access to the highest attainable standards of health without distinction of gender, race, religion, belief, income, or social class.' SA has similarly set a high bar for access to healthcare: section 27 of the SA Constitution ${ }^{[3]}$ entails that the state must provide for the progressive realisation of the right to access healthcare services within available resources, while emergency care is an absolute right. SA is also committed to universal health coverage, defined as providing people and communities with needed healthcare that is of sufficient quality to be effective without imposing financial hardship on users, and has embarked on an ambitious programme to achieve this via the National Health Insurance (NHI) reforms. ${ }^{[4]}$ However, COVID-19 has highlighted and accentuated the extent to which the SA healthcare system, and particularly the public healthcare system, falls short in meeting these important goals. ${ }^{[5,6]}$

While there are many factors contributing to why healthcare delivery in SA is not fulfilling its promise, the long-term mismatch between the resources available in the health system and stated national health policy must be considered one of the most important. The gap is also influenced by stark inequities between the care available to those dependent on the tax-funded public health system v. those able to pay for private services. In 2017, total health expenditure in SA ranged between $8 \%$ and $9 \%$ of the gross domestic product, which is comparable to other upper middle-income countries. ${ }^{[7]}$ Although this equates to expenditure of $\sim$ ZAR8 500 per person per year, it is skewed towards the $\sim 16.4 \%$ of the population ${ }^{[8]}$ who are able to afford to purchase medical scheme cover, and those who pay out of pocket for private sector care, where expenditure is estimated at >ZAR20 000 per person per year. In contrast, expenditure towards the care of those dependent on the public health system amounts to ZAR5 000 per annum. ${ }^{[7]}$ While it is substantially better resourced, real rates of contribution increases in the private sector of $560 \%$ from 1980 to 2016 and the potential unaffordability of these increases triggered the Health Market Inquiry (HMI), which found gross inefficiencies in the private sector insurance and healthcare delivery markets. ${ }^{[9]}$

While the NHI reform intends to capitalise on the potential efficiencies and economies of scale that might be realised from pooling public and private resources in a unified health system, the money currently spent by private individuals on their healthcare is not immediately available to the state to finance the NHI system. As others have argued, 'medical scheme members are unlikely to hand over these high contributions to the state ... without the assurance of an equivalent service in return. ${ }^{[10]}$ Although it may be possible to re-channel a proportion of private healthcare spending to the public sector through smart regulation, taxation and financing strategies, ${ }^{[4]}$ 
this would also increase demand on NHI as people seek NHIprovided care over private provision. So, while the net impact of NHI on average per capita expenditure is uncertain, the demand for care is likely to exceed available financing and supply. We therefore argue that equity-informed priority-setting within the public and private health sectors must be based on a realistic estimate of the short- to medium-term available resources, and not be based on aspirational approaches.

\section{Impact of COVID-19}

The COVID-19 pandemic is likely to widen the healthcare demandsupply gap. On the supply side, the pandemic has had and will have a devastating impact on the economy, ${ }^{[1]}$ where losses include ZAR304 billion in tax revenue contributing towards debt forecasts of ZAR4 trillion during the 2020/21 financial year. ${ }^{[12]}$ The capacity and/or willingness of government to increase the allocation of resources for healthcare, let alone retain current levels, is limited. ${ }^{[11]}$ Losses of at least 2.2 million jobs suggest that the numbers of people who can afford private cover or to pay for services out of pocket will be greatly reduced. ${ }^{[13]}$

On the demand side, COVID-19 has led to a huge re-allocation and some increase in government expenditure, not only within healthcare but also within other sectors such as social development. Within healthcare, COVID-19 has directly increased the demand for COVID-19-related programmes. In the June 2020 supplementary budget review, a total of ZAR21.5 billion was re-prioritised to public health services. ${ }^{[1]}$ The funding was earmarked for spending in three broad areas: (i) public health interventions, including early detection of cases through community screening and testing, contact tracing, disease surveillance, public health campaigns to reduce transmission of the virus in communities, and support to the National Institute for Communicable Diseases; (ii) expanding hospital capacity and critical care to accommodate larger volumes of patients through the establishment of field hospitals and other temporary facilities, procuring equipment, recruiting staff and buying medicines, and contracting with the private sector to supplement public sector capacity; and (iii) procuring personal protective equipment, hospital beds, capacity for managing quarantine and isolation, linen, oxygen and ventilators, and hiring new staff. While it is welcome that the ZAR21.5 billion was based on a national health sector COVID-19 cost model, it is noteworthy that the majority is not new money, but was shifted from existing priorities within provincial equitable share. ${ }^{[14]}$ In addition, ongoing allegations of corruption in the public health system raise questions about the extent to which this money was spent efficiently or on the intended purposes. ${ }^{[15]}$

Going forward, the public healthcare system will also face an increasing demand for care related to increased levels of hunger and deprivation, and the inability of large sections of the population to access required non-COVID healthcare services during the pandemic. In addition, there is evidence that COVID-19 is reducing demand for other services in the short term, which is likely to result in increased demand in the post-COVID environment. ${ }^{[16,17]}$

\section{How do we manage the gap?}

Given the resource constraints and the way the healthcare system in $\mathrm{SA}$ is structured and managed, the gap between available resources and the claims on them is wide. Continuance of the mismatch between stated national health policy $\mathrm{v}$. what is delivered within public facilities will further: (i) undermine the government's credibility and its ability to deliver on longer-term social goals such as NHI; (ii) increase the already high level of dissatisfaction with services provided by the public health system; ${ }^{[8]}$ and (iii) demoralise health workers who know that they simply cannot deliver what is promised with the resources provided.

The key question then is: 'If all the healthcare services that are promised cannot be provided, what will be provided?' This problem is not new. All countries grapple with the ethical, political and financial issues of what healthcare to provide in their own ways. The landmark publication of Fuch's Who Shall Live ${ }^{[18]}$ in 1974 explored health economics and priority-setting in the US context, and Newdicks' Who Should We Treat ${ }^{\text {?19] }}$ in 1995 examined how the British NHS could manage fair allocation of resources. An expansive literature on methods and processes for priority-setting has followed, which fundamentally aims to address the difficult reality that choices in healthcare need to be made. However, while hard choices are inevitable, progress can be made regarding the extent to which choices are considered to be fair. In an implicit approach, there are no clear rules as to what services will be provided or what services people will be entitled to, and decisions are made on a discretionary basis by managers, professionals, and other health personnel functioning within a fixed budgetary allowance. With explicit priority-setting, decisions as to the amounts and types of resources to be made available, eligible populations, and specific rules for allocation are explicitly stated and informed by economic analysis to maximise value and to achieve social goals. ${ }^{[2,21]}$

The most transparent and comprehensive approach to prioritysetting in SA's public health system is currently at the national level in the selection of medicines for the national Essential Medicines List. While the decision rules for this process include considerations of resource constraints and equity, ${ }^{[22]}$ it is not clear how different elements of resource use and clinical benefit are compared. Going forward, consideration should be given to including a fuller consideration of cost offsets (e.g. reductions in length of stay) and budget impact to further strengthen the extent to which selected medicines are affordable. In contrast to medicines, there are limited established priority-setting processes for including other technologies within the public health system. Examples of aspirational approaches to setting priorities include the 2030 Human Resources for Health Strategy, ${ }^{[23]}$ which estimates that 88000 additional public healthcare workers are needed by 2025 to deliver on the benefits package defined by national policy, and the service-level agreement to purchase intensive care services for management of patients with COVID-19, which was expected to be a cost-ineffective investment. ${ }^{[2,25]}$

In addition to national approaches, there is limited routine public information on how provinces make decisions or the extent to which they are able to implement national priorities, including for COVID-19. ${ }^{[26]}$ This is important, because the federal fiscal system provides provincial treasuries with autonomy over the allocation of their 'equitable shares', meaning that different provinces allocate different per capita amounts to fund public facilities. ${ }^{[10]}$ Because there is no clear link between stated national priorities and available resources at a provincial level, the public health system inevitably relies on implicit rationing using passive mechanisms such as waiting lists, unfilled staffing posts and limited facility opening hours, all of which contribute to inequitable access to care. The approach in the private sector is more explicit, with a reliance on Prescribed Minimum Benefits (PMBs), utilisation management and benefit limits. However, as evidenced by the findings of the Health Market Inquiry, there have been shortcomings in the key underlying support mechanisms, most notably in the regulatory environment and the technical support systems to review the PMBs on an ongoing basis..$^{[9]}$ 


\section{Steps requilied}

SA's public health system currently relies on priority-setting approaches that lead to implicit rationing of services. A key challenge in managing the expected widening of the demand-supply gap as a result of the COVID-19 pandemic is the need to improve our approach to priority-setting. We would argue that this can be achieved on an incremental basis by shifting towards approaches that are more explicit in their consideration of opportunity cost and equity. If national priorities are affordable, we expect that this will enhance the extent to which provinces can implement them or can be held accountable for implementation. We should discourage approaches that rely predominantly on an understanding of intervention effectiveness and that are either silent or aspirational regarding future healthcare resources. While calls for the need to review how we approach priority-setting are not new, ${ }^{[27]}$ the COVID19 pandemic has lent urgency to the need to move beyond discussion, and towards substantive policy and research action. ${ }^{[28]}$

Explicitly considering opportunity cost and equity in order to set priorities will be challenging both procedurally and analytically. How do we maximise the health of the population, taking into account the burden of disease and availability of effective interventions; the distribution of health services and equity in access; budgetary constraints; and political and community preferences? To ensure fair explicit prioritisation, we need to develop the processes that allow for participation of all stakeholders, and we need to fast-track implementation of the technical support systems and institutions that can provide the evidence and stakeholder input to support such prioritisation. In doing so, we can learn from the many countries that have implemented processes of health technology assessment that include considerations of opportunity cost and equity. ${ }^{[29]}$ The establishment of such processes has long been mooted in National Department of Health strategy documents, ${ }^{[1]}$ was a key recommendation of the Health Market Inquiry, ${ }^{[9]}$ and is a key step to the implementation of NHI. ${ }^{[4]}$ COVID-19 makes the implementation of these plans more urgent.

Declaration. None.

Acknowledgements. The authors would like to acknowledge the institutional support of the South African Medical Research Council (SAMRC) and University of Cape Town provided to the study authors.

Author contributions. Conceived and designed the study: GCS, TW, SMC. Developed the manuscript: GCS, TW, SMC. Reviewed the manuscript: ED, DB, CRTT, SD.

Funding. GCS is employed on a contractual basis by the SAMRC and NMG Consultants and Actuaries. Support in the form of salaries was provided by the SAMRC for authors GCS, ED and DB, and by the University of Cape Town for TW, SMC, CRTT and SD. None of these institutions had any additional role in the study design, data collection and analysis, decision to publish, or preparation of the manuscript.

Conflicts of interest. GCS is employed on a contractual basis by NMG Consultants and Actuaries, an independent consulting firm providing consulting and actuarial services to SA private health insurance funds. NMG did not have any role in the study design, data collection and analysis, decision to publish, or preparation of the manuscript. As such, there were no conflicts of interest in the conduct of the study.
1. Department of Health, South Africa. White Paper: National Health Insurance Policy. Towards Universal Coverage. 2017. http://www.health.gov.za/index.php/nhi-documents? download=2257:whiteversal Coverage. 2017. http://www.health.gov.

2. World Health Organization. Constitution of the World Health Organization. 2006. https://www. who.int/governance/eb/who_constitution_en.pdf (accessed 7 November 2020).

3. South Africa. Constitution of the Republic of South Africa, 1996. https://www.justice.gov.za/ legislation/constitution/SAConstitution-web-eng.pdf (accessed 7 November 2020).

4. South Africa. National Health Insurance Bill, B11-2019. 2019. https://www.gov.za/sites/default/ files/gcis_document/201908/national-health-insurance-bill-b-11-2019.pdf (accessed 7 Novembe 2020)

5. Erasmus D. After R45bn in irregular expenditure over 10 years, KZN health department ill prepared for Covid-19 storm. Daily Maverick, 7 August 2020. https://www.dailymaverick.co.za/article/202008-07-after-r45bn-in-irregular-expenditure-over-10-years-kzn-health-department-ill-preparedfor-covid-19-storm/ (accessed 7 November 2020).

6. Ellis E. Saving Eastern Cape from Covid-19 existential threat. Daily Maverick, 20 June 2020. https://

6. Ellis E. Saving Eastern Cape from Covid-19 existential threat. Daily Maverick, 20 June 2020. https://
www.dailymaverick.co.za/article/2020-06-30-saving-eastern-cape-from-covid-19-existentialwww.dailymaverick.co.za/article/2020-
threat/ (accessed 7 November 2020).

7. World Bank. World Development Indicators. 18 June 2020. https://databank. worldbank.org/home. aspx (accessed 7 November 2020).

8. Statistics South Africa. General Household Survey, 2018. Statistical release PO318. 2018. http:// www.statssa.gov.za/publications/P0318/P03182018.pdf (accessed 7 November 2020).

9. Competition Commisssion of South Africa. Health Market Inquiry: Final findings and recommendations report. September 2019. http://www.compcom.co.za/wp-content uploads/2020/01/Final-Findings-and-recommendations-report-Health-Market-Inquiry.pdf (accessed 7 November 2020).

10. Michel J, Tediosi F, Egger M, et al. Universal health coverage financing in South Africa: Wishes vs reality. J Global Health Rep 2020;4:e2020061. https://doi.org/10.29392/001c.13509

11. Department of National Treasury, South Africa. Supplementary Budget Review. 24 June 2020 http://www.treasury.gov.za/documents/National\%20Budget/2020S/review/FullSBR.pdf (accessed 7 November 2020)

12. Merten M. Tito Mboweni asks for a 'mini budget' delay - a worrying sign the economic line isn't holding. Business Maverick, 13 October 2020. https://www.dailymaverick.co.za/article/2020 10-13-tito-mboweni-asks-for-a-mini-budget-delay-a-worrying-sign-the-economic-line-isntholding/?utm_medium=email\&utm_campaign=Business (accessed 7 November 2020).

13. Ranchod V, Bassier I, Budlender J, et al. 2. Employment. An overview of results from the NIDSCRAM Wave 1 2020. https://cramsurvey.org/wp-content/uploads/2020/07/Spaull-et-al.-NIDSCRAM-Wave-1-Synthesis-Report-Overview-and-Findings-1.pdf (accessed 7 November 2020).

14. Maynier D. Western Cape Government Provincial Treasury: First adjusted estimates, 2020 Maynier D. Western Cape Government Provincial Treasury: First adjusted estimates, 2020
speech. 23 July 2020 . https://www.westerncape.gov.za/provincial-treasury/files/atoms/files/ speech. 23 July 2020. https: //www.westerncape.gov.za/provincial-treasury/files/atoms/files/
Minister\%27s\%20Speech $\% 20$ - $\% 20$ First $\% 20$ Adjustment $\% 20$ Budget $\% 202020 \% 20$ - $\% 20$ Final_ For\%20Publishing.pdf (accessed 7 November 2020).

15. Ho U. Gauteng government tries to defend corruption report as just that, a report. Daily Maverick, 28 August 2020. https://www.dailymaverick.co.za/article/2020-08-28-gauteng-government-triesto-defend-the-procurement-corruption-report-as-just-that-a-report/ (accessed 7 Novembe 2020)

16. Spaull N, Ardington C, Bassier I, et al. Overview and Findings NIDS-CRAM Synthesis Report Wave 1. 2020. https://cramsurvey.org/wp-content/uploads/2020/07/Spaull-et-al.-NIDS-CRAMWave-1-Synthesis-Report-Overview-and-Findings-1.pdf (accessed 7 November 2020).

7. Medical Brief. Academy of Sciences: Costs of COVID-19 to SA's quadruple disease burden. 8 July 2020. https://www.medicalbrief.co.za/archives/academy-of-sciences-costs-of-covid-19-to-sasquadruple-disease-burden/ (accessed 7 November 2020).

18. Fuchs VR. Who Shall Live?: Health, Economics, and Social Choice. Singapore: World Scientific, 2011.

18. Newdick C. Who Should We Treat?: Law, Patients and Resources in the NHS. Oxford: Oxford University Press, 1995.

University Press, 1995 .
20. Glassman A, Giedion U, Smith PC, eds. What's In, What's Out: Designing Benefits for Universal Glassman A, Giedion U, Smith PC, eds. What's In, What's Out: Designing
Health Coverage. 2017. Washington, DC: Brookings Institution Press, 2017.

21. Chalkidou K, Glassman A, Marten R, et al. Priority-setting for achieving universal health coverage. Bull World Health Organ 2016;94(6):462. https://doi.org/10.2471/blt.15.155721

22. Leong TD, McGee SM, Gray AL, et al. Essential medicine selection during the COVID-19 pandemic: Enabling access in uncharted territory. S Afr Med J 2020;110(11):1077-1080. https://doi org/10.7196/SAMJ.2020.v110i11.15271

23. Cleary S, Wilkinson T, Tchuem CT, et al. MOSAIC: A model to assess the cost-effectiveness of ICU strategies for the South African COVID-19 response. 14 September 2020. https://zivahub.uct.ac.za/ articles/dataset/MOSAIC_A_model_to_assess_the_cost-effectiveness_of_ICU_strategies_for_the articles/dataset/MOSAIC_A_model_to_assess_the_cost-effectiveness_of_ICU

24. Solanki G, Wilkinson T, Tchuem CT, et al. Covid-19 surge: Investing heavily in ICU capacity is not the only option. Daily Maverick, 29 May 2020. https://www.dailymaverick.co.za/article/2020-05-29-covid19-surge-investing-heavily-in-icu-capacity-is-not-the-only-option/ (accessed 7 November 2020).

25. National Department of Health, South Africa. 2030 human resources for health strategy: Investing in the health workforce for universal health coverage. 2020. https://www.gov.za/sites/default/files/ gcis_document/201409/dohdrafthrstrategyconsultation.pdf (accessed 7 November 2020).

26. Van den Heever A. South Africa sets aside more money for COVID-19 but lacks a spending strategy. The Conversation, June 2020. https://theconversation.com/south-africa-sets-aside-more-moneyfor-covid-19-but-lacks-a-spending-strategy-141619 (accessed 7 November 2020).

27. Hofman KJ, McGee S, Chalkidou K, et al. National Health Insurance in South Africa: Relevance of a national priority-setting agency. S Afr Med J 2015;105(9):739-740. https://doi.org/10.7196/ SAMJnew.8584

28. Wilkinson T, Cleary S, Tchuem CT, et al. Dexamethasone is not the Covid-19 'silver bullet' we are looking for. Daily Maverick, 9 July 2020. https://www.dailymaverick.co.za/article/2020-07-09are looking for. Daily Maverick, 9 July 2020 . https://www.dailymaverick.co.za/article/2020-07-09-
dexamethasone-is-not-the-covid-19-silver-bullet-we-are-looking-for/\#gsc.tab $=0$ (accessed 7 Novemdexamethas
ber 2020).

ber 2020).
29. Li R, Hernandez-Villafuerte K, Towse A, et al. Mapping priority setting in health in 17 countries across Asia, Latin America, and sub-Saharan Africa. Health Syst Reform 2016;2(1):71-83. https:// doi.org/10.1080/23288604.2015.1123338

Accepted 26 October 2020. 